\title{
New palaeomagnetic results from Late Paleozoic volcanic units along the western Gondwana margin in La Pampa, Argentina
}

\author{
Renata Nela Tomezzoli ${ }^{1,2}$, Teresa Saint Pierre ${ }^{2}$, and Claudia Valenzuela ${ }^{2}$ \\ ${ }^{1}$ Consejo Nacional de Investigaciones Científicas y Técnicas (CONICET), Buenos Aires, Argentina \\ ${ }^{2}$ Departamento de Ciencias Geológicas, Facultad de Ciencias Exactas y Naturales, Universidad de Buenos Aires, \\ Ciudad Universitaria, 1428, Pabellón II, Buenos Aires, Argentina
}

(Received October 4, 2007; Revised May 4, 2008; Accepted May 9, 2008; Online published January 23, 2009)

\begin{abstract}
Preliminary palaeomagnetic results from the Paleozoic volcanic units along the Gondwana margin in Argentina are presented. Even though we are still working on the palaeomagnetic data of the sampled section, these data are consistent with data from former studies carried out in the area. More than 90 specimens were measured from the Sierra Chica locality $\left(37^{\circ} 52^{\prime} \mathrm{S} ; 6^{\circ} 27^{\prime} \mathrm{W}\right)$ computed in 11 sites $(\mathrm{Sc} 1-\mathrm{Sc} 11)$. These rocks are carriers of a characteristic remanence magnetization with reverse polarity, acquired during the Early Permian and assigned to the Kiaman Superchron. The resulting palaeomagnetic pole (PP) is Lat.: $64^{\circ} \mathrm{S}$; Long.: $017^{\circ} \mathrm{E}, A_{95}=15^{\circ}$, $K=12, N=10$. Others interpretations are also possible if the directions of two sites (SC9 and SC10) are considered to have a different magnetic field record. In that case, the PP calculated for sites Sc1-Sc7 is Lat.: $65^{\circ} \mathrm{S}$; Long.: $44^{\circ} \mathrm{E}, A_{95}=8^{\circ}, K=54, N=7$, and the virtual geomagnetic pole (VGP) calculated for sites Sc9 and Sc10 is Lat.: $48.5^{\circ} \mathrm{S}$; Long.: $315^{\circ} \mathrm{E}, A_{95}=8^{\circ}, N=2$. The last possibility to consider Sc9 and Sc10 after structural correction, and the resulting PP position is Lat.: $66.5^{\circ} \mathrm{S}$; Long.: $034^{\circ} \mathrm{E}, A_{95}=8^{\circ}, K=41, N=9$. This deformation episode could be related to the San Rafaelic orogenic phase, found for the first time in La Pampa province, but previously observed in other neighboring areas during Permian time. However, more detailed palaeomagnetic sampling, rock magnetism studies, and age dating are necessary to complete the palaeomagnetic study of this area.
\end{abstract}

Key words: Gondwana, Choiyoi volcanism, palaeomagnetism, Late Paleozoic, South America.

\section{Introduction}

To improve upon our understanding of the evolution of the Western Gondwana during the Late Paleozoic to Early Mesozoic and to explore regional relationships between sedimentation, volcanism, and the age of the deformation, new palaeomagnetic studies are underway in the Gondwanides belt (Keidel, 1916) or "Samfrau Geosynclinal" (Du Toit, 1927) exposed in the central Argentina (Fig. 1). In this work, a preliminary study is reported from Sierra Chica $\left(37^{\circ} 52^{\prime} \mathrm{S} ; 65^{\circ} 27^{\prime} \mathrm{W}\right)$, and we will compare the results with those from other studies of Late Paleozoic rocks along this belt. The areas included in the study are found in the Sierras Australes $\left(38^{\circ} \mathrm{S}, 62^{\circ} \mathrm{W} ; 55\right.$ sites on sedimentary rocks; Tomezzoli and Vilas, 1999; Tomezzoli, 2001) and the Carapacha basin $\left(38^{\circ} \mathrm{S}, 65^{\circ} 5 \mathrm{~W} ; 24\right.$ sites on sedimentary and volcanic rocks; Tomezzoli et al., 2006; Fig. 1). The earlier studies yielded two paleomagnetic directions, one of them in the Lower Permian and the other in the Lower Upper Permian, indicating that the rocks were remagnetized during a relatively short period of time. The palaeogeographic implication of these data for South America is consistent with a latitudinal and counterclockwise movement of the continent between the Early and Late Permian times. This movement

Copyright (c) The Society of Geomagnetism and Earth, Planetary and Space Sciences (SGEPSS); The Seismological Society of Japan; The Volcanological Society of Japan; The Geodetic Society of Japan; The Japanese Society for Planetary Sciences; TERRAPUB. has been interpreted to be the consequence of a late adjustment between the continental blocks before the assembly of Pangea (Tomezzoli, 2001, 2005). Palaeomagnetism in this case can be useful in the comparisons of the regional Choiyoi magmatism along this deformed belt, establishing the age of the deformation by region.

\section{Geological Setting}

The volcanic rocks of Sierra Chica $\left(37^{\circ} 52^{\prime} \mathrm{S} ; 65^{\circ} 27^{\prime} \mathrm{W}\right.$; Fig. 2) are located in the Southern part of the Chadileuvú Block (Llambías et al., 1996), in La Pampa province, central Argentina (Fig. 1). This volcanism is part of the Choiyoi Group, the Permian-Triassic igneous rocks, whose extension in Argentina exceeds $500,000 \mathrm{~km}^{2}$ (Llambías et al., 2003). In La Pampa, the Choiyoi Group has characteristics similar to those elsewhere, such as an abundance of mesosilicic to silicic ignimbrites, subvolcanic domes, and granite plutons emplaced at shallow levels (Llambías et al., 2003). However, the most important difference between the Choiyoi Group from La Pampa and that from the Cordillera frontal and the San Rafael Block (Fig. 1) is that the San Rafael orogenic phase (Lower Permian) is not obvious in La Pampa (Llambías et al., 2003). Therefore, it is not possible to attribute a postorogenic character to the Choiyoi Group in La Pampa, as has been done in the Cordillera frontal and in the San Rafael Block (Llambías et al., 2003). The Choiyoi Group in La Pampa is located in a tectonically stable environment adjacent to the active continental margin (Llambías 


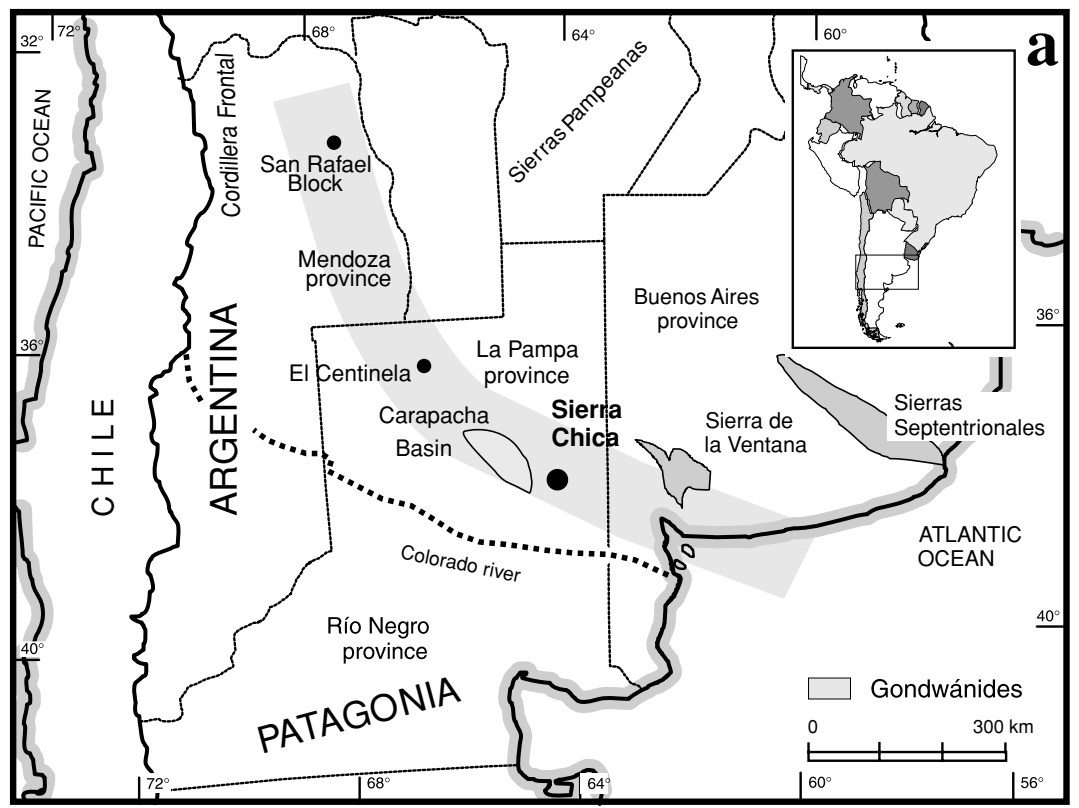

Fig. 1. Location of the Sierra Chica locality in the deformed orogenic belt known as "Gondwanides belt" in the Central Argentina. Other localities are also indicated in this study: Sierra de la Ventana, Carapacha Basin, Cerro El Centinela and San Rafael Block (modified from Tomezzoli et al., 2003).

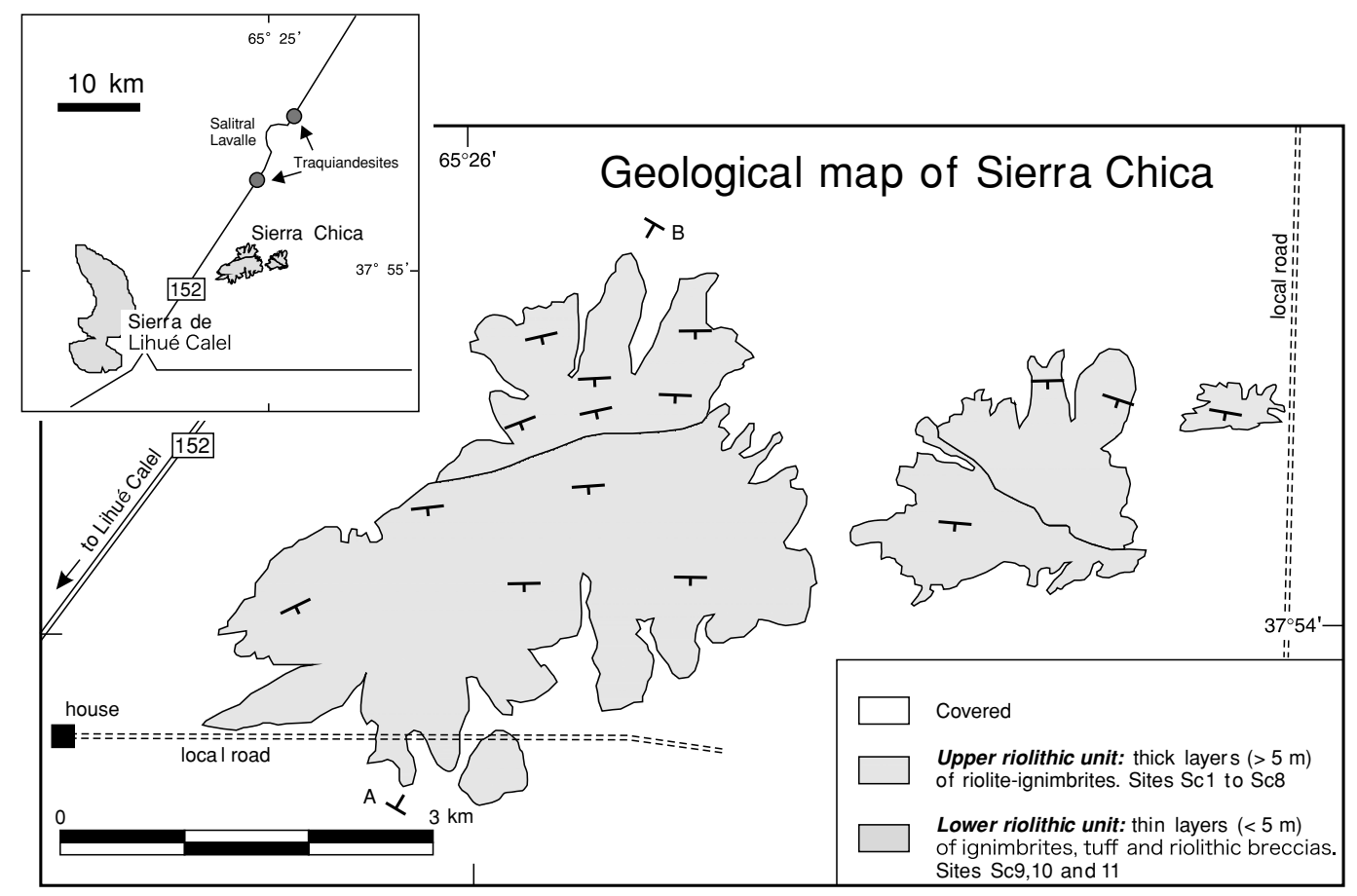

Fig. 2. Geological map of the Sierra Chica with the location of the three mentioned units (taken and modified from Quenardelle and Llambías, 1997). Sampling sites are located along the A-B profile.

et al., 2003).

The Sierra Chica is a positive element that forms one of the topographic highs of the La Pampa landscape (Quenardelle and Llambías, 1997). The sequence is composed of three units. The first and lowermost unit (northern) consists of trachyandesitic pyroclastic flows of unknown thickness and extent. The other two rhyolitic units are divided into the lower unit, composed of well-bedded, thin $(<7 \mathrm{~m})$ pyroclastic units interbedded with thin fall units (Fig. 2), and the upper unit, composed of coarse bedded, thick py- roclastic layers (10-20 m) with rheomorphic characteristics (Quenardelle and Llambías, 1997; Fig. 2). Chemical data show that all three units have high-K calc-alkaline chemistry with metaluminous to slight peraluminous tendencies (Quenardelle and Llambías, 1997). Lithologic evidence suggests that these rocks are proximal to the effusion center and probably represent a remanent of a volcanic cone. The strike and dip of the averaged measured stratification plane in the lower group is 068/18; in contrast, the massif aspect of the rocks in the upper group makes it difficult to measure 
Table 1. Palaeomagnetic results for a total of 86 specimens from 11 sites in the Sierra Chica.

\begin{tabular}{|c|c|c|c|c|c|c|c|c|c|c|}
\hline Site & $N / n$ & $\begin{array}{l}\text { Dec. }^{\circ} \\
\text { Sierra }\end{array}$ & $\begin{array}{l}\text { Inc. }{ }^{\circ} \\
n \text { situ } \\
\text { ca }\end{array}$ & $\alpha_{95^{\circ}}$ & $k$ & \multicolumn{5}{|c|}{$\begin{array}{l}\text { with bedding correction } \\
\mathbf{1 0 0 \%} \text { unfolding }\end{array}$} \\
\hline $\mathrm{Sc}^{*} \bullet$ & $9 / 5(4)$ & 146 & 43 & 6.5 & 67 & & & & & \\
\hline $\mathrm{Sc} 2 * \bullet$ & $9 / 9$ & 148.5 & 55 & 6 & 66 & & & & & \\
\hline $\mathrm{Sc} 3^{*} \bullet$ & $9 / 3$ & 170 & 46 & 12 & 101 & & & & & \\
\hline Sc $4 * \bullet$ & $10 / 5(2)$ & 154 & 32 & 13 & 22 & & & & & \\
\hline $\mathrm{Sc}^{*} \bullet$ & $4 / 1$ & 161 & 56 & 4 & - & & & & & \\
\hline $\mathrm{Sc}^{*} \bullet$ & $9 / 4(4)$ & 147 & 45 & 8 & 51.5 & & & & & \\
\hline $\mathrm{Sc}^{*} \bullet$ & $7 /(6)$ & 151 & 30 & 8 & 121 & & & & & \\
\hline Sc8 & $8 / 4(3)$ & 111 & 54 & 4 & 256 & & & & & \\
\hline $\mathrm{Sc} 9^{* *}$ & $8 / 7$ & 136.5 & 80 & 10 & 40 & $068 / 18 \bullet$ & 150 & 62 & 10 & 40 \\
\hline $\operatorname{Sc} 10^{* *}$ & $9 / 6(2)$ & 127 & 81 & 8 & 51 & $068 / 18 \bullet$ & 147 & 64 & 8 & 51 \\
\hline Sc11 & $4 /-$ & - & - & - & - & & & & & \\
\hline Mean & $10 / 10$ & 148 & 53 & 12 & 17 & & & & & \\
\hline Mean* & 7 & 154 & 44 & 9 & 47 & & & & & \\
\hline Mean*** & 2 & 132 & 80.5 & - & - & $* *$ & 149 & 63 & - & - \\
\hline Mean• & 9 & 153 & 48 & 8.5 & 37 & & & & & \\
\hline
\end{tabular}

Site, Mean high temperature characteristic directions in the Sierra Chica; $N / n$, number of processed specimens/number of directional components used in the calculation of the mean; $n$, number of great circles used in the calculation of the mean; Dec., declinations $\left({ }^{\circ}\right)$; Inc., inclinations $\left({ }^{\circ}\right) ; \alpha_{95}\left({ }^{\circ}\right)=$ semiangle of the $95 \%$ confidence cone; $k$, Fisher statistical parameter (Fisher, 1953); bedding, strike and dip (left hand rule). *; **; •, sites mean directions used in the calculation of the media. See also Fig. 5.

stratification planes in this section. However, it is clear that they dip in the same direction but very gently (less than $5^{\circ}$ ). The Sierra Chica sequence is consistent with an eruption in an extensional tectonic regime immediately subsequent to a subduction-related compressional regime (Quenardelle and Llambías, 1997).

Rapela et al. (1996) obtained an Rb-Sr whole-rock isochron age of $240 \pm 2$ Ma from the Lihué Calel rhyolite that included samples of Sierra Chica trachyandesites (Fig. 2), suggesting a cogenetic source for both units. However, the eruptive characteristics of the Sierra Chica rhyolitic units along with their chemistry indicate that the Sierra Chica flows are from a different source than the more silicic, fluorite-bearing Lihué Calel flows that outcrop a few kilometers to the southwest and which also belong to the Choiyoi magmatic sequence (Quenardelle and Llambías, 1997; Fig. 2). New U-Pb zircon dating in the area is being processed.

\section{Laboratory Procedures}

The sampling sites in the Sierra Chica are distributed along the A-B profile (Fig. 2). Each site represents a different cooling layer. Three hand samples were collected per site and oriented in the field using a magnetic compass. Typically standard cylindrical specimens (2.2 (long) $\times 2.5 \mathrm{~cm}$ (diameter)) were cut from each core. A total of 86 specimens from 11 sites on volcanic rocks were studied (Table 1). Measurements of natural remanent magnetization (NRM) were made using a DC-squid cryogenic magnetometer ( $2 \mathrm{G}$ model $750 \mathrm{R})$. Standard high-temperature demagnetization techniques were selected as the demagnetization procedure. Thermal demagnetization was successfully applied in at least 15 steps, with maximum temperatures of $680^{\circ} \mathrm{C}$, using an ASC oven with dual chambers. Bulk susceptibility was measured in all specimens after each step to monitor possible chemical changes during heating, using a Bartington MS2 susceptibility meter. Demagnetization results were analyzed using orthogonal vector plots (Zijderveld, 1967) and stereographic projections. Palaeomagnetic directions were determined using principal component analysis (Kirschvink, 1980) or using the remagnetization plane technique (Halls, 1976). The final site mean directions were compiled using Fisher (1953) statistics; alternatively, in the case of combined directional data and remagnetization great circles, the method of McFadden and McElhinny (1988) was used.

Natural remanent magnetization intensities range in general from 30 to $3,000 \mathrm{~mA} \mathrm{~m}^{-1}$. In some of the samples, as in the case of the $\mathrm{Sc} 3$ site, the values are up to $10,000 \mathrm{~mA} \mathrm{~m}^{-1}$, and the directional results for these samples were poor. The samples present different behavior, but most were very stable during heating, with a gradual decay towards the origin (Fig. 3). All components were isolated with a maximum angular deviation of $15^{\circ}$. For those remanence directions which were stable during heating, with a gradual decay to the origin (Fig. 3(a)), unblocking temperatures range between $630^{\circ}$ and $680^{\circ} \mathrm{C}$, showing that this magnetization is carried by a mineral of the titano-hematite series. In other samples, demagnetization paths were curved along great circles, indicating the simultaneous removal of distinct magnetic components with overlapping unblocking temperatures, which ranged from $550^{\circ}$ to $580^{\circ} \mathrm{C}$, suggesting that the magnetization is carried by titano-magnetite (Fig. 3(b)). The magnetic behavior at the $\mathrm{Sc} 9$ and $\mathrm{Sc} 10$ sites was different from that at the remaining sites (Fig. 3(c)). In those cases, it was possible to isolate a component with a different direction, and the unblocking temperatures were found to range from $530^{\circ}$ and to $630^{\circ} \mathrm{C}$. The experiments of isothermal remanent magnetization (IRM) acquisition in the representative behaviors showed that the main carriers of the remanence are both low and high coercivity minerals (Fig. 4; Dankers, 1978; Dekkers, 1988). A second 


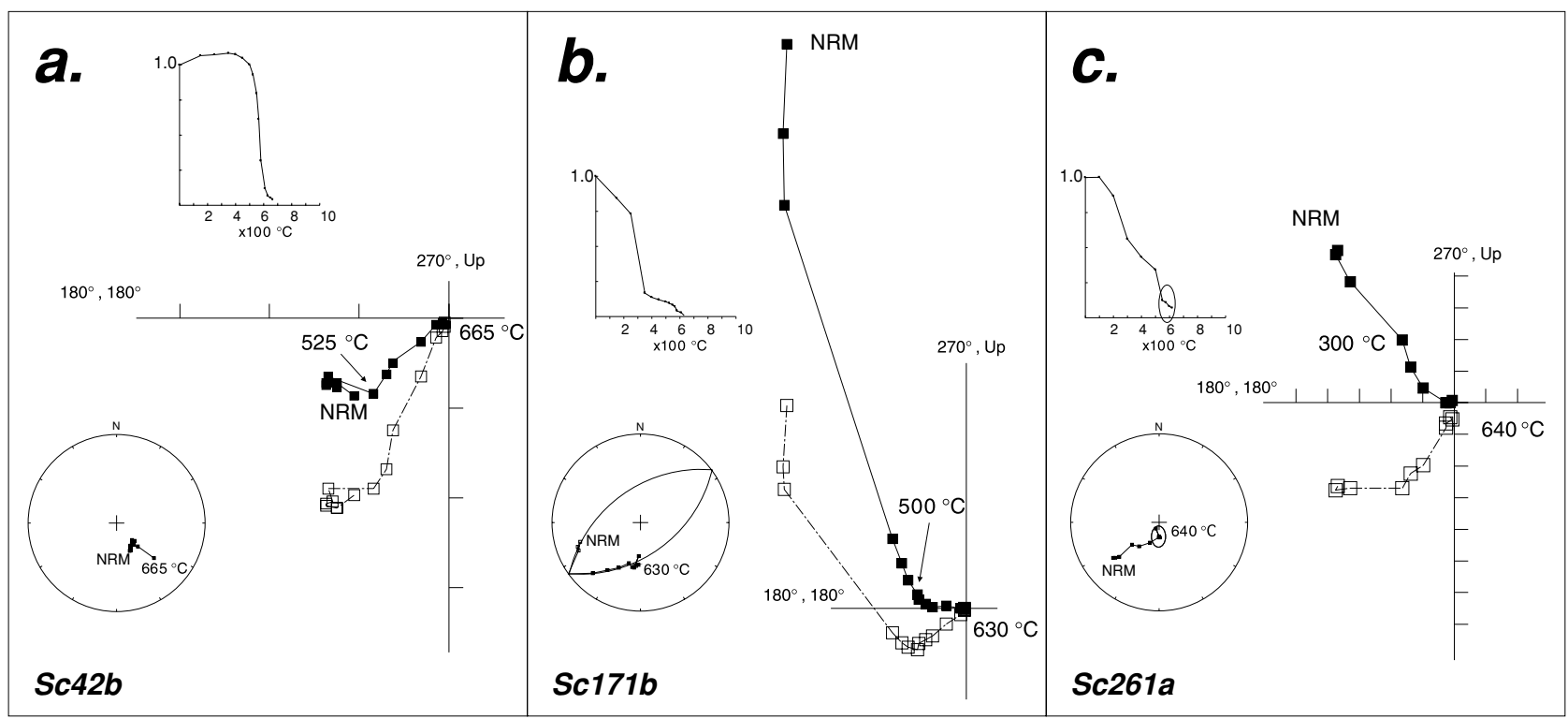

Fig. 3. Representative thermal demagnetization results for selected specimens. (a) I: Zijderveld diagrams. Open (filled) squares indicate vertical (horizontal) plane projections, in geographic coordinates. II: Demagnetization curves. III: Equal-area projection. (b) Remagnetization circle is shown. (c) Example of the behavior in sites Sc9 and Sc10.

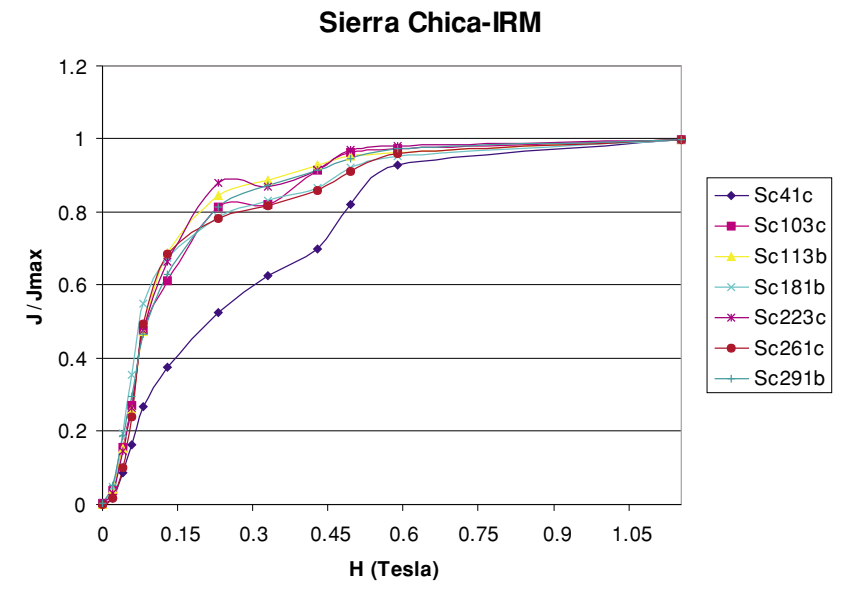

Fig. 4. Experiments of IRM acquisition in the representative behaviors showed that the main carriers of the remanence are both low and high coercivity minerals.

low-temperature component between $100^{\circ}$ to $400^{\circ} \mathrm{C}$ was isolated in some specimens, with random directions. The low unblocking temperatures and the scattered distribution indicate that this component is a secondary magnetization, probably of recent vintage. Consequently, it is not considered relevant for tectonic interpretations.

In most samples it was possible to isolate one characteristic component in the southeast quadrant (in situ) with a positive inclination (Table 1, Fig. 5) and good within-site groupings $\left(\alpha_{95}<15^{\circ}\right.$ and $\left.k>20\right)$, referred as Population 1; the exception is Sc11, where it was not possible to isolate any component. For this reason, palaeomagnetic data from this site were rejected. The sites SC8, SC9, and SC10 are located in the well-bedded lower rhyolitic unit (described by Quenardelle and Llambías, 1997; Fig. 2, Table 1) and present a different characteristic direction with respect to the other site directions (Fig. 5, Table 1). The direction of

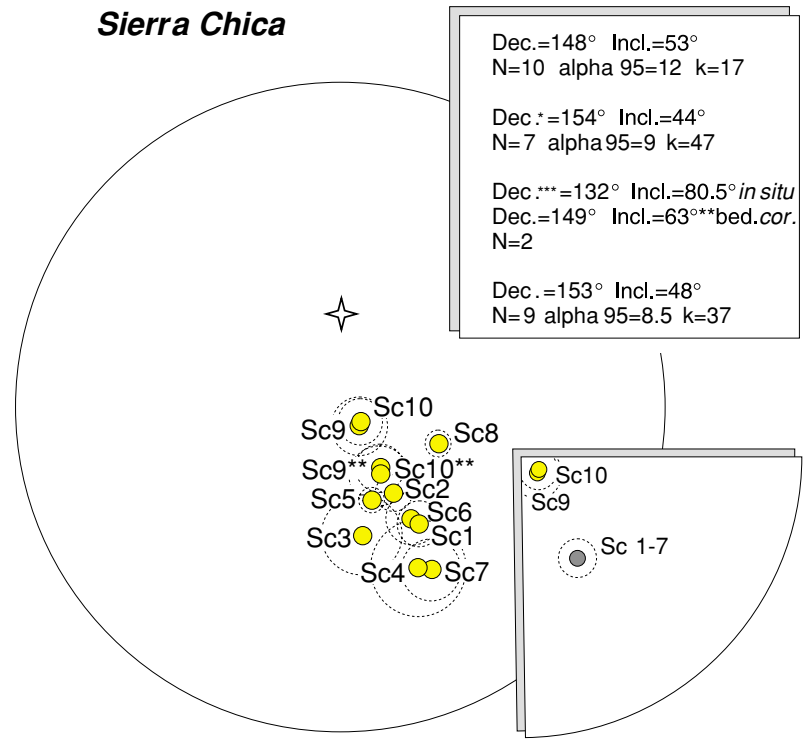

Fig. 5. High-temperature characteristic remanence directions (in equal area projections) in situ and with bedding correction for sites Sc9 and Sc10**. Present field direction (\& symbol) and the media for sites Sc1-7 are indicated. Also see also Table 1.

Sc8 was isolated at only one site, and for that reason this direction will be considered separately from the other sites.

The in situ mean direction (Fig. 5) when the ten accepted (Sc1-Sc10) sites are considered is $D .=148^{\circ}, I .=53^{\circ}$, $\alpha_{95}=12^{\circ}, k=17$ (see also Table 1, Fig. 5). No bedding correction was applied in the upper units because these are sub-horizontal. As the Sc9 and Sc10 characteristic mean directions seem to be displaced from the mean direction provided by the SC1-Sc7 sites (Fig. 5), a different outlining analysis has been proposed to test statistically whether these means correspond to two different populations. We have applied the reversal test of McFadden and McElhinny (1990). 
Table 2. Late Paleozoic and early Mesozoic South American poles selected from the cratonic areas of South America.

\begin{tabular}{|c|c|c|c|c|c|c|c|}
\hline \multirow[t]{2}{*}{ Paleomagnetic pole } & \multirow[b]{2}{*}{$A_{95^{\circ}}$} & \multicolumn{2}{|c|}{ Site } & \multicolumn{2}{|c|}{ Pole } & \multirow[b]{2}{*}{ AGE (PP) } & \multirow[b]{2}{*}{ References } \\
\hline & & LAT. $^{\circ}$ & LONG. $^{\circ}$ & PLAT. $^{\circ}$ & PLONG. $^{\circ}$ & & \\
\hline Gonzalez Chaves Ar & 17 & -38 & 300 & -84 & 216 & $248.5-\mathrm{Tr}$ & Tomezzoli and Vilas (1997) \\
\hline Amana Ar & 8 & -30.3 & 292.3 & -83 & 317 & $248.5-1 \mathrm{Tr}$ & Valencio et al. (1977) \\
\hline Independencia Pr & 6.6 & -24 & 304 & -80.7 & 7.0 & 260-uP-1Tr & Rapalini et al. (2006) \\
\hline Sierra Chica 1-10ce & 8 & -37.5 & 333 & -66.5 & 034 & 260-240?1P & This work \\
\hline Sierra Chica 1-7 & 8 & -37.5 & 333 & -65 & 044 & 260-240?1P & This work \\
\hline Sierra Chica 1-10 & 15 & -37.5 & 333 & -64 & 017 & 260-240?1P & This work \\
\hline San Roberto & 11 & -38.2 & 294.2 & -70 & 49 & 270-up & Tomezzoli et al. (2006) \\
\hline Alto Paraguay Pr & 6 & -24 & 302.5 & -78 & 319 & $245-\operatorname{Tr}$ & Ernesto (2005) \\
\hline Tunas II Ar & 5.2 & -38.2 & 298.6 & -74.1 & 25.9 & 275-ulP & Tomezzoli (2001) \\
\hline Cochicó & 17.5 & -34.5 & 291 & -60.3 & 007 & 285-2801P & Tomezzoli et al. (2005) \\
\hline Rio Curacó Ar & 5 & -38.1 & 294.1 & -64 & 005 & $280 \mathrm{lP}$ & Tomezzoli et al. (2006) \\
\hline Itararé I2 Br. & 4 & -21.5 & 312.8 & -60.3 & 29.5 & 290-1P & Pascholati (1983) \\
\hline Tunas I Ar. & 5.1 & -38 & 298.2 & -63 & 13.9 & 290-1P & Tomezzoli and Vilas (1999) \\
\hline Sierra Chica 9-10 & - & -37.5 & 333 & -48.5 & 315 & $290 ?-1 \mathrm{P}$ & This work \\
\hline Lw. Colorados Ar & 5 & -29.5 & 293 & -60 & 358 & 293-1P & Embleton (1970) \\
\hline La Colina Ar. & 8 & -30 & 293 & -49 & 343 & 294-1P & Sinito et al. (1979) \\
\hline Itarare I Br. & 4 & -21.5 & 312.8 & -56.7 & 350.6 & 295-1P & Pascholati (1983) \\
\hline Tepuel Ar. & 8.5 & -43.5 & 289.6 & -31.7 & 316 & $318-1 \mathrm{C}$ & Rapalini et al. (1994) \\
\hline
\end{tabular}

Paleomagnetic poles (PPs) were taken from Van der Voo (1993) and McElhinny and Lock (1996); the Global Palaeomagnetic Database and the data were checked with the original contributions. $A_{95}\left({ }^{\circ}\right)=$ semi-angle of the $95 \%$ confidence cone. The PPs were selected based on a minimum of three of the reliability criteria of Van der Voo (1990); see Fig. 6.

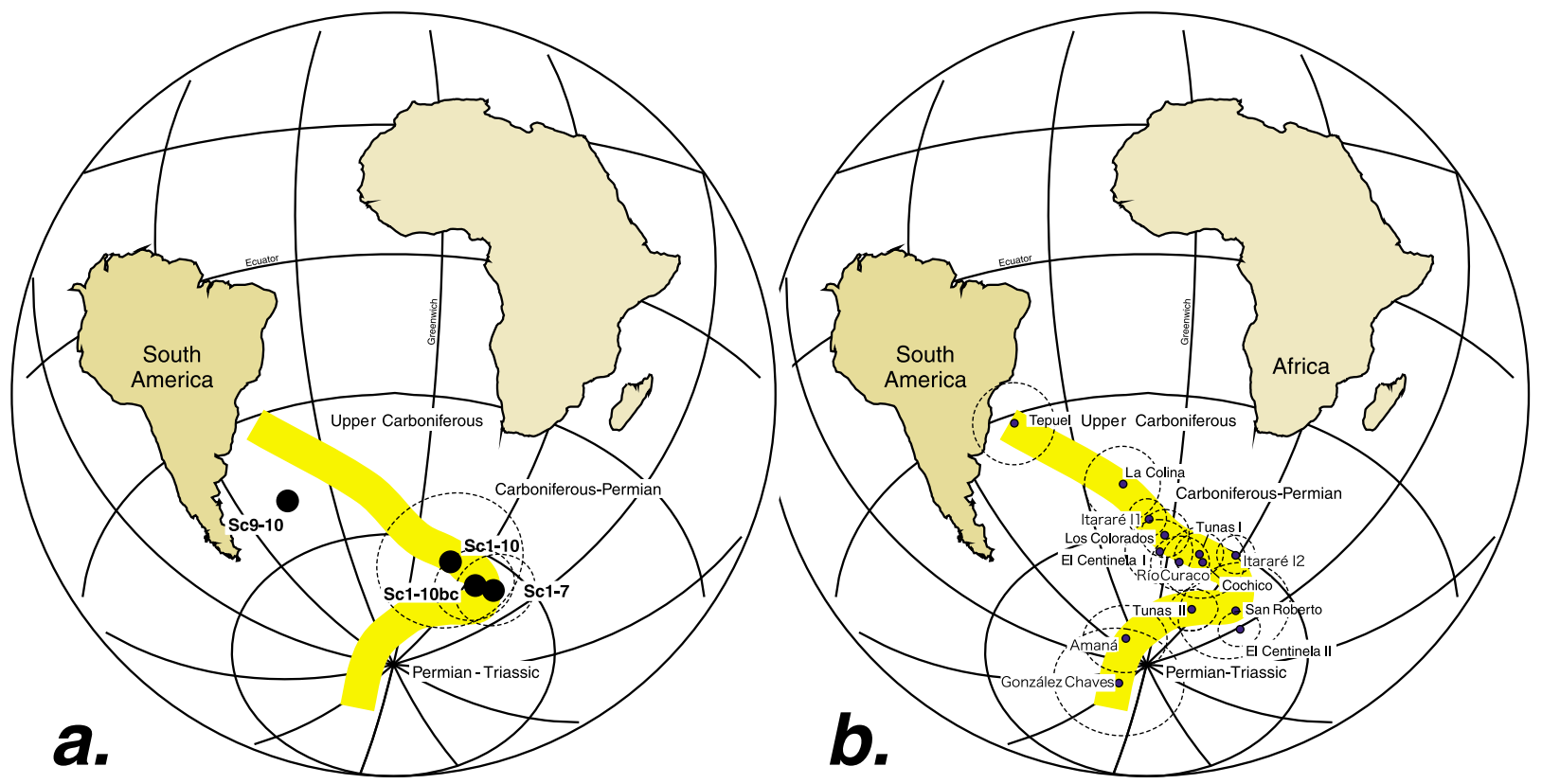

Fig. 6. Late Paleozoic and early Mesozoic South American paleomagnetic poles from the cratonic region are shown (see Table 2), selected with a minimum of three of the reliability criteria of Van der Voo (1990). (a) Sierra Chica PP calculated based on the different sites mean direction (see on the text). Sa. Chica 1-10 (sites Sc1-Sc10); Sa. Chica 1-7 (Sc1-Sc7); Sa. Chica 9-10 (Sc9-10); Sa. Chica 1-10ce (sites Sc1-Sc7 in situ with nine to ten bedding corrected). (b) Position of the palaeomagnetic poles shown on the APWP for South America in the latest Paleozoic.

The test was negative (value of test statistic $=127.6$, with a $95 \%$ confidence limit $=7.9$ and a $99 \%$ confidence limit $=14.1)$, which indicates that SC9 and SC10 constitute a different population of directions (Fig. 5). The media in situ direction without considering Sc8, Sc9 and Sc10 is $D .=154^{\circ}, I .=44^{\circ}, \alpha_{95}=9^{\circ}, k=47, N=7$ (see also Table $1\left(^{*}\right)$, Fig. 5). The media in situ between $\mathrm{Sc} 9$ and $\mathrm{Sc} 10$ is $D .=132^{\circ}, I .=80.5^{\circ}, N=2$ (see also Table $1\left(^{* * *}\right)$ and Fig. 5). If the bedding correction is applied to sites Sc9 and Sc10, the media results are $D .=149^{\circ}$, $I .=63^{\circ}, N=2$ (see also Table $1\left(^{* *}\right)$, Fig. 5). However, if the Sc9 and Sc10 directions (bedding corrected ${ }^{* *}$ ) are considered with the rest of the directions in situ, the final media is: $D .=153^{\circ}, I .=48^{\circ}, \alpha_{95}=8.5^{\circ}, k=37, N=9$ (see also Table 1 (filled circle), Fig. 5). 


\section{Discussion}

The Sierra Chica volcanic rocks have a characteristic stable remanent magnetization in the southeast quadrant (in situ), with exclusively reverse polarity and good within-site grouping. According to the assigned age of these rocks, this magnetization was acquired during the Kiaman reverse Superchron. As the top of the Kiaman is approximately $266 \mathrm{Ma}$ (Gradstein et al., 2004), this result implies an older age for these rocks. New U-Pb zircon ages in the area are being processed. The characteristic magnetization is a single high-blocking temperature component carried by titano-magnetites, titano?-hematite, or both. More rock magnetism studies should be carried out with the aim to characterize the magnetic carriers.

As the behavior and the characteristic mean direction of Sc9 and Sc10 sites seem to be different than the other site mean directions, the directional analysis has been done in different ways, considering one or two directions as a different record of the magnetic field, respectively. One mean direction was between the $\mathrm{Sc1-Sc7}$ sites and the other was between the Sc9 and Sc10 sites (see Table 1, Fig. 5). In this case, the mean direction of site Sc8 was not considered in the calculation of the PPs because it differed from the two principal groups of direction (Sc1-Sc7 and Sc9Sc10) and could be considered to be an oblique direction of the magnetic field. The associated PP was computed from the VGPs. The best grouping of those vectors in situ were averaged to obtain the Sierra Chica pole: Lat.: $64^{\circ} \mathrm{S}$; Long.: $017^{\circ} \mathrm{E}, A_{95}=15^{\circ}, K=12, N=10$ (Fig. 6, Table 2). This position is consistent with the apparent polar wander path (APWP) of South America from other lower Permian PP from neighboring areas (Table 2, Fig. 6). However, if the Sc9 and Sc10 mean directions are treated separately (see Table 1) the results change. The PP calculated for sites Sc1-Sc7 is Lat.: $65^{\circ} \mathrm{S}$; Long.: $044^{\circ} \mathrm{E}, A_{95}=8^{\circ}, K=54$, $N=7$ (Fig. 6(a), Table 2), and the VGP calculated for sites $\mathrm{Sc} 9$ and $\mathrm{Sc} 10$ in situ is Lat.: $48.5^{\circ} \mathrm{S}$; Long.: $315^{\circ} \mathrm{E}$, $N=2$ (Fig. 6(a), Table 2). In this case, the PP position in the APWP is consistent with the stratigraphy of the sites because sites Sc9 and Sc10 are in the oldest rhyolitic units of the sequence (Quenardelle and Llambías, 1997) and occupy an older position in the APWP (Figs. 2, 6(a)), while sites Sc1-Sc7 are younger and belong to the upper rhyolitic units (Quenardelle and Llambías, 1997; Figs. 2, 6(a)). In this case the stratigraphic plane measured in the Sc9 and Sc10 sites (068/18) should have a primary volcanic origin, which is not unusual in the volcanic products closer to the effusive center. An alternative interpretation of the mean direction would be to consider the direction of $\mathrm{Sc} 9$ and $\mathrm{Sc} 10$ after making a bedding correction; in this case, the PP calculated for sites Sc1-Sc10 is Lat.: $66.5^{\circ} \mathrm{S}$; Long.: $034^{\circ} \mathrm{E}$, $A_{95}=8^{\circ}, K=41, N=9$ (Fig. 6(a), Tables 1,2). The deformation should have developed after the deposition of the lower units but before the deposition of the upper units, in which case this deformation episode could be related with the San Rafaelic orogenic phase registered in others areas (Tomezzoli and Vilas, 1999; Tomezzoli, 2001). In any case, all of the calculated PPs are consistent with positions in the APWP during the late Early Permian to early Late Permian (Fig. 6(b)).
There also exists the possibility that the secular variation was not adequately averaged out. However, the paleopolar position is consistent with the positions of the other PPs of the Late Paleozoic APWP of South America in neighboring areas (Fig. 6(b); Tomezzoli et al., 2006). New age dating studies in different stratigraphic positions of the column and more detailed palaeomagnetic sampling are necessary in this area to complete this study.

Acknowledgments. All processing was carried out using the following software: Criolapd and Estereográfica-GR (E. O. Cristallini); IAPD (T. H. Torsvik); Cirdi (M. Mena); Mag88 (E. Oviedo). We are especially grateful to A. Rapalini who provided the samples for this study. C. Vazquez is thanked for help in the continuous maintenance of the equipment. We thank the editor A. Gogichaishvili, M. Domeier, and two reviewers for constructive reviews. This work was funded by the Fundación Antorchas: Subsidio de Apoyo a Proyectos, PIP-CONICET 5758 and PICT38295 .

\section{References}

Dankers, P. H. M., Magnetic properties of dispersed natural iron-oxides of known grain-size, $\mathrm{PhD}$ thesis, pp. 143, Rijksuniversiteit te Utrecht, Utrecht, the Netherlands, 1978.

Dekkers, M. J., Some rock magnetic parameters for natural goethite, pirrhotite and fine grained hematite. Geologica Ultraiectina, $\mathrm{PhD}$ thesis, pp. 231, University of Utrecht, Utrecht, the Netherlands, 1988.

Du Toit, A., A geological comparison of South America with South Africa, 381, 1-157, Carnegie Institute of Washington Publications, Washington D.C., 1927.

Embleton, B. J. J., Paleomagnetic results for the Permian of South America and a comparison with the African and Australian data, Geophys. J. R. Astron. Soc., 21, 105-118, 1970.

Ernesto, M., New Early Triassic paleomagnetic pole for South America from the Alto Paraguay Alkaline Province, Joint Assembly AGU, New Orleans, USA, Abstracts: GP-41A-08, 2005.

Fisher, R. A., Dispersion on a sphere, Proc. R. Soc. Lond. Ser. A, 217, 295-305, 1953.

Gradstein, F., J. Ogg, and A. Smith, A geologic time scale 2004, 589 pp., Cambridge University Press, New York, 2004.

Halls, H. C., A least squares method to find a remanence direction from converging remagnetization circles, Geophys. J. R. Astron. Soc., 45, 297-304, 1976.

Keidel, J., La geología de las sierras de la Provincia de Buenos Aires y sus relaciones con las montañas del Cabo y los Andes. Ministerio de Agricultura Nacional. An. Dirección Nacional Geol. Minería. IX (3), Buenos Aires, 1916.

Kirschvink, J. L., The least squares line and plane and the analysis of paleomagnetic data, Geophys. J. R. Astron. Soc., 62, 699-718, 1980.

Llambías, E. J., R. N. Melchor, H. Tickyj, and A. M. Sato, Geología del Bloque de Chadileuvú, XIII Congreso Geológico Argentino y III Congreso de Exploración de Hidrocarburos, Actas V, 417-425, Buenos Aires, 1996.

Llambías, E. J., S. Quenardelle, and T. Montenegro, The Choiyoi Group from Central Argentina: a subalkaline transitional to alkaline association in the craton adjacent to the active margin of Gondwana continent, J. South Am. Earth Sci., 16, 243-257, 2003.

McElhinny, N. W. and J. Lock, IAGA paleomagnetic databases with, Access. Surv. Geophys., 17, 575-591, 1996.

McFadden, P. L. and N. W. McElhinny, The combined analysis of remagnetization circles and direct observations in paleomagnetism, Earth Planet. Sci. Lett., 87, 161-172, 1988.

McFadden, P. L. and M. W. McElhinny, Classification of the reversal test in palaeomagnetism, Geophys. J. Int., 103, 725-729, 1990.

Pascholati, E. M., Possibilidade de interferencias termais do magnetismo Juro-cretácico na analise paleomagnética do Grupo Itarare. Atlas do 4 Simposio Regional de Geologia, SBG, 211-222, Sao Paulo, 1983.

Quenardelle, S. M., and E. J. Llambías, Las riolitas de Sierra Chica $\left(37^{\circ} \mathrm{S}\right.$, $\left.65^{\circ} \mathrm{O}\right)$ : un centro eruptivo gondwánico en el bloque del Chadileuvú, provincia de La Pampa, Argentina. Rev. Asoc. Geol. Argentina, 52(4), 549-558, 1997.

Rapalini, A. E., D. H. Tarling, P. Turner, S. Flint, and J. F. Vilas, Paleo- 
magnetism of the Carboniferous Tepuel Group, central Patagonia, Argentina, Tectonics, 13(5), 1277-1294, 1994.

Rapalini, A. E., S. Fazzito, and D. Orué, A new Late Permian paleomagnetic pole for stable South America: the Independencia Group, eastern Paraguay, Earth Planets Space, 58, 1247-1253, 2006.

Rapela, C. W., R. J. Pankhurst, E. J. Llambías, C. Labudía, and A. Artabe, "Gondwana" magmatism of Patagonia: Inner cordilleran calc-alkaline batholiths and bimodal volcanic provinces, Proc. Third Int. Symp. Andean Geodynamics, 791-794, Saint Malo, 1996.

Sinito, A. M., D. A. Valencio, and J. F. Vilas, Paleomagnetism of a sequence of Upper Paleozoic-Lower Mesozoic red beds from Argentina, Geophys. J. R. Astron. Soc., 58, 237-247, 1979.

Tomezzoli, R. N., Further paleomagnetic results from the Sierras Australes fold and thrust belt, Argentina, Geophys. J. Int., 147, 356-366, 2001.

Tomezzoli, R. N., A Large counterclockwise movement of Western Gondwana during the Upper Paleozoic, infered from paleomagnetic data, Gondwana 12, Mendoza, 2005.

Tomezzoli, R. N. and J. F. Vilas, Paleomagnetismo y fábrica magnética en afloramientos cercanos a las Sierras Australes de la Provincia de Buenos Aires (López Lecube y González Chaves), Rev. Asoc. Geol. Argentina, 52(4), 419-432, 1997.

Tomezzoli, R. N. and J. F. Vilas, Paleomagnetic constraints on age of deformation of the Sierras Australes thrust and fold belt, Argentina, Geophys. J. Int., 138, 857-870, 1999.

Tomezzoli, R. N., W. D. MacDonald, and H. Tickyj, Composite magnetic fabrics from S-C granitic gneiss of Cerro de los Viejos, La Pampa province, Argentina, J. Struct. Geol., V25/2, 159-169, 2003.

Tomezzoli, R. N., L. Kleiman, J. Salvarredi, C. Terrizzano, and E. O. Cristallini, Paleogeographic evolution of the Southwest Gondwana boundary during the late Paleozoic. Paleomagnetism of the lower Choiyoi volcanics in the San Rafael block, Mendoza, Argentina. ISAG. Extended Abstracts, 730-733, Barcelona, 2005.

Tomezzoli, R. N., R. Melchor, and W. D. MacDonald, Tectonic implications of post-folding Permian magnetizations, Carapacha basin, Argentina. Paleomagnetism in Latinoamerica, Earth Planets Space, 58, 1235-1246, 2006.

Valencio, D. A., J. F. Vilas, and J. E. Mendia, Paleomagnetism of a sequence of red beds of the middle and the upper sections of Paganzo Group (Argentina) and the correlation of upper Paleozoic-lower Mesozoic rocks, Geophys. J. R. Astron. Soc., 51, 59-74, 1977.

Van der Voo, R., The reliability of paleomagnetic data, Tectonophysics, 184, 1-9, 1990.

Van der Voo, R., Paleomagnetism of the Atlantic, Tethys and Iapetus oceans, pp. 411, Cambridge University Press, Cambridge, 1993.

Zijderveld, A. C., Demagnetization of rocks: Analysis of results, in Methods in Paleomagnetism, edited by D. W. Collinson, K. M. Creer, and S. K. Runcorn, pp. 254-286, Elsevier, Amsterdam, 1967.

R. N. Tomezzoli (e-mail: renata@gl.fcen.uba.ar), T. Saint Pierre, and C. Valenzuela 